\title{
LA LITIGACIÓ CLIMÀTICA A ESPANYA: UNA PROSPECTIVA
}

\section{Climate litigation in Spain: A pRospective}

\author{
JORDI JARIA-MANZANO \\ Professor agregat Serra Húnter de Dret constitucional i ambiental \\ Universitat Rovira i Virgili \\ jordi.jaria@urv.cat
}

Recibido: 26 de octubre de 2018 / Aceptado: 11 de diciembre de 2018

RESUM: La dependència de les institucions tradicionals de producció normativa d'estructures de poder transnacionals i opaques, en el context de la fase global i financera de l'evolució sistema-món capitalista. desplaça progressivament l'èmfasi, en relació amb l'adaptació i mitigació del canvi climàtic, des de la regulació a l'adjudicació, del poder legislatiu al poder judicial. És per això que, en els últims anys, s'ha desenvolupat progressivament la litigació climàtica. Casos emblemàtics, com Urgenda, als Països Baixos, i Juliana, als Estats Units, han posat de manifest que l'espai forense esdevé un àmbit útil i innovador per impulsar la reacció social davant de la transformació antròpica del Sistema Terra, permetent la participació activa d'actors no institucionals i l'apoderament de la ciutadania. D'aquesta manera, es poden desplegar estratègies de control del poder i exigència de responsabilitats, amb la finalitat de permetre la transformació progressiva de la presa de decisions per ajustar-la a les exigències de la transició cap a l'Antropocè. En aquest marc, es proposa una anàlisi prospectiva de la litigació climàtica a Espanya, a partir dels fonaments constitucionals.

RESUMEN: La dependencia de las instituciones tradicionales de producción normativa de estructuras de poder transnacionales y opacas, en el contexto de la fase global y financiera de la evolución del sistema-mundo capitalista, 
desplaza progresivamente el énfasis en la adaptación y mitigación del cambio climático desde la regulación a la adjudicación, del poder legislativo al poder judicial. Es por ello que, en los últimos años, se ha desarrollado progresivamente la litigación climática. Casos emblemáticos, como Urgenda, en los Países Bajos, y Juliana, en Estados Unidos, han puesto de manifiesto que el espacio forense deviene un ámbito útil e innovador para impulsar la reacción social ante la transformación antrópica del Sistema Tierra, permitiendo la participación activa de actores no institucionales y el empoderamiento de la ciudadanía. De este modo, se pueden desplegar estrategias de control del poder y exigencia de responsabilidades que permitan la transformación progresiva de la toma de decisiones para ajustarla a las exigencias de la transición hacia el Antropoceno. En este marco, se propone un análisis prospectivo de la litigación climática en España, a partir de los fundamentos constitucionales.

ABSTRACT: The dependence of the traditional normative powers regarding the transnational and opaque structures of the capitalist world-system, in its global and financial phase, moves progressively the emphasis from regulation to adjudication, from the legislative to the judiciary, in the shaping of social responses of adaptation and mitigation regarding climate change. In this context, in recent years, climate litigation has been developed. Leading cases, as Urgenda, in the Netherlands, or Juliana, in the United States, have underlined that the courts have become a useful and innovative space to propel the social reaction, confronting the anthropic transformation of the Earth System and allowing the active participation of non-institutional actors, as well as the empowerment of the citizens. With this, people can deploy strategies of control of power, accountability and demand of liabilities, allowing the transformation of decision-making processes to adjust them to the needs of the transition to the Anthropocene. Within this framework, this paper aims to provide an appraisal of climate litigation in Spain, starting from its constitutional foundations.

PARAULES CLAU: Canvi climàtic — Litigació — Sostenibilitat — Justícia.

PALABRAS CLAVE: Cambio climático - Litigación - Sostenibilidad Justicia. 
KEYWORDS: Climate Change — Litigation — Sustainability — Justice.

SUMARI: I. Introducció. II. L'Antropocè i el canvi climàtic. III. Sostenibilitat, justícia climàtica i drets humans. IV. La litigació climàtica: un panorama general. V. Control i responsabilitat en la protecció del medi ambient: la posició del Tribunal Constitucional. VI. Back to Basics: la Constitució Espanyola i les perspectives de la litigació climàtica a Espanya. VII. Prospectiva sobre la litigació climàtica a Espanya. IX. Conclusions. X Bibliografia.

\section{INTRODUCCIÓ}

Els episodis indicatius del canvi climàtic es multipliquen a mesura que el temps avança i l'evidència científica en relació amb el fenomen augmenta paral-lelament. La complexitat i les implicacions del canvi climàtic, amb la progressiva presa de consciència sobre la seva materialització, es projecten en el conjunt dels sabers i les pràctiques socials i, per suposat, també en el món del dret $^{1}$. En aquest sentit, és cosa sabuda que les polítiques d'adaptació i mitigació relacionades amb el canvi climàtic han donat lloc a un seguit d'estratègies reguladores, tant en el terreny internacional, com en el context del dret supraestatal, l'estatal i, fins i tot, l'infraestatal, des de la signatura de la Convenció contra el Canvi Climàtic l'any $1992^{2}$.

Tanmateix, cal reconèixer que els escenaris en els quals es produeixen aquestes regulacions són extremadament sensibles a la defensa aferrissada d'una certa concepció de l'interès nacional, així com a les pressions de la indústria implicada en la generació dels gasos d'efecte hivernacle (GEH), tenint en compte la clara dependència del sistema-món capitalista de les energies fòssils ${ }^{3}$. Tot plegat fa que hi hagi un cert escepticisme en relació amb la seva efectivitat ${ }^{4}$. D'altra banda, en el context intern, els fenòmens de captura del legislador en relació amb les

\footnotetext{
1 John S. Dryzek, Richard B. Norgaard i David Schlosberg, a "Climate Change and Society: Approaches and Responses", John S. Dryzek, Richard B. Norgaard, David Schlosberg (eds.), The Oxford Handbook of Climate Change and Society, Oxford University Press. Oxford, 2011, p. 3 , assenyalen que el canvi climàtic "presents perhaps the most profund challenge ever to have confronted human social, political, and econòmic Systems".

2 Vid. la Convenció Marc de les Nacions Unides sobre el Canvi Climàtic (CMNUCC), feta a Nova York el 9 de maig de 1992, el text oficial de la qual en la versió castellana està disponible a $<$ https://unfccc.int/files/essential_background/background_publications_htmlpdf/application/pdf/ convsp.pdf> [consultat el 10 de setembre de 2018].

${ }^{3}$ Aquesta seria la tesi que desenvolupa Andreas Malm a Fossil Capital. The Rise of Steam Power and the Roots of Global Warming, Verso. Londres, 2016.

${ }^{4}$ Vid. Sam Adelman, "Climate change, human rights and corporate accountability", Stephen Humphreys (ed.), Human Rights and Climate Change, Cambridge University Press. Cambridge, Nueva York, 2010, p. 163.
} 
polítiques energètiques són notoris i tenen una incidència remarcable en les estratègies dels estats en relació amb el canvi climàtic, amb conseqüències que es projecten sobre l'eficàcia d'uns acords internacionals que no responen a una acció concertada i ambiciosa que respongui la gravetat del fenomen ${ }^{5}$. És per això que existeix, en els darrers anys, una certa presa de consciència en la relació amb la necessitat de dissenyar estratègies complementàries per activar la reacció social i política en relació amb el canvi climàtic.

És en aquest context on cal ubicar la litigació climàtica, que esdevé un instrument a l'abast de la societat civil organitzada per incidir sobre unes polítiques climàtiques que venen configurades d'una manera que no garanteix una reacció apropiada, atesa la importància i la urgència del repte, el qual, en realitat, implica la modificació antròpica del Sistema Terra en unes proporcions inaudites i potencialment catastròfiques ${ }^{6}$. D'aquesta manera, es pot considerar que és necessari un trasllat de l'èmfasi en la reacció social davant del canvi climàtic des de l'interès per la regulació, subjecte a les limitacions que deriven del joc diplomàtic en l'arena internacional i del fenomen de la captura del legislador en l'àmbit intern, cap a l'adjudicació, això és, la intervenció dels tribunals en conflictes concrets, que pot tenir com a resultat decisions que impulsin polítiques efectives, així com, en general, canvis en el capteniment dels actors que causen el canvi climàtic ${ }^{7}$.

Es constata, efectivament, que la litigació climàtica ha augmentat en la darrera dècada. Particularment, ha estat notable l'evolució del fenomen als Estats Units.

\footnotetext{
${ }^{5}$ Sobre el concepte de la regulatory capture, vid. Ernesto Dal Bó, "Regulatory Capture: A Review", Oxford Review of Economic Policy 22(2), 2006, p. 203-225. Sobre la pressió que exerceixen determinats actors informals, particularment actors corporatius, en la presa de decisions sobre les institucions formalment democràtiques, vid. Peter Evans, " $¿ E l$ eclipse del Estado? Reflexiones sobre la estatalidad en la época de la globalización", Miguel Carbonell, Rodolfo Vázquez (eds.), Globalización y Derecho, Ministerio de Justicia y Derechos Humanos. Quito, 2009, p. 46. Específicament referit al cas espanyol, vid. Jordi Jaria i Manzano, "Constitución, desarrollo y medio ambiente en un contexto de crisis", Revista Catalana de Dret Ambiental 8(1), 2017, p. 19ss.; i Alba Nogueira López, "Crisis económica y cambios estructurales en el régimen de ejercicio de actividades", Avelino Blasco Esteve (coord.), El Derecho público de la crisis económica. Transparencia y sector público. Hacia un nuevo Derecho administrativo, INAP. Madrid, 2011, p. 139.

${ }^{6}$ Vid. Bo Kjellén, "Justice in global environmental negotiations: the case of desertification", Jonas Ebbeson, Phoebe Okowa (eds.), Environmental Law and Justice in Context, Cambridge University Press. Cambridge, Nova York, 2009, p. 334.

${ }^{7}$ Walter F. Baber i Robert V. Bartlett, a "The Role of International Law in Global Governance", Dryzek, Norgaard, Schlosberg, The Oxford Handbook... cit., p. 660ss., es refereixen a les limitacions del dret internacional per reaccionar adequadament davant del canvi climàtic i posen de manifest, en particular, el dèficit democràtic que acompanya a la pràctica diplomàtica normal.
} 
Altres indrets de l'àmbit del common law han generat, així mateix episodis interessants en l'evolució de la litigació climàtica, cosa que també ha succeït en diverses jurisdiccions asiàtiques, com és el cas del Pakistan o de les Filipines, per posar dos exemples significatius. En l'àmbit europeu continental, el cas que ha tingut més impacte i que ha generat una atenció generalitzada, particularment en aqueles jurisdiccions en la tradició del civil law, ha estat Urgenda, als Països Baixos, un leading case l'impacte del qual és difícil de menystenir. En definitiva, es pot considerar que la litigació climàtica ha anat fent el seu camí en els darrers anys, amb aconseguiments notables, en múltiples jurisdiccions, representatives de tradicions jurídiques ben diverses ${ }^{8}$. És per això que sembla raonable ocuparse de les possibilitats de la litigació climàtica en el sistema jurídic espanyol, que, fins al moment, ha estat poc destacat en aquest àmbit ${ }^{9}$. El que planteja aquest estudi, atesa la situació, és, en conseqüència, una anàlisi prospectiva sobre les possibilitats de la litigació climàtica a Espanya, tot prenent en consideració, fonamentalment, el marc constitucional de protecció del medi ambient.

\section{L'ANTROPOCÈ I EL CANVI CLIMÀTIC}

A hores d'ara, sembla que és reconegut de manera majoritària que l'escalfament del sistema climàtic és inequívoc i que, en les darreres dècades, s'han experimentat canvis que no tenen precedents en els darrers mil·lennis, cosa que pot observar-se tant en els mesuraments històrics de temperatura de l'atmosfera i dels oceans, al mateix temps que en la disminució de la quantitat de gel en el conjunt del planeta i en l'augment del nivell dels oceans ${ }^{10}$. El darrer informe del

\footnotetext{
8 Un panorama recent de l'evolució es pot copsar a United Nations Environment Programme, The Status of Climate Change Litigation - A Global Review, 2017.

${ }^{9}$ En l'informe esmentat, la única referència al cas espanyol es produeix en relació amb la litigació impulsada per empreses en relació amb les assignacions realitzades pel Reial Decret 1866/2004, de 6 de setembre, pel que s'aprova el Pla nacional d'assignació de drets d'emissió, 2005-2007 (BOE núm. 216, de 7 de setembre de 2004).

${ }^{10}$ Per a l'evidència disponible sobre el canvi climàtic, cal consultar els informes realitzats pel panell internacional d'experts, disponibles a <http://www.ipcc.ch/publications_and_data/publications_and_data.shtml> [consultat el $10 \mathrm{de}$ setembre de 2018]. Particularment, vid. Intergovernmental Panel on Climate Change, Climate Change 2014. Synthesis Report, 2014, p. 40ss. Les dades i la interpretació proporcionades pel panell han estat discutides, però, en general, hom tendeix a considerar poc sòlides les posicions més escèptiques, a banda de què aquells que les mantenen tendeixen a tenir fortes relacions amb els interessos corporatius vinculats a l'explotació de les energies fòssils. Vid., en aquest sentit, Sheila Jasanoff, "Cosmopolitan Knowledge: Climate Science and Global Civic Epistemology”, Dryzek, Norgaard, Schlosberg, The Oxford Handbook... cit., p. 130. Per a una
} 
Panell Intergovernamental sobre el Canvi Climàtic (IPCC) és concloent en relació amb la producció del canvi climàtic i el seu origen en l'activitat humana, cosa que el constitueix en la mostra més clara de la transformació antròpica del Sistema Terra ${ }^{11}$. Efectivament, el canvi climàtic ha esdevingut del patró de la representació de la intensitat, la gravetat i la perillositat de la modificació humana de la biosfera, si més no en les darreres tres dècades ${ }^{12}$.

Com és sabut, l'augment de la capacitat antròpica de transformació del Sistema Terra ha estat tan gran en les últimes dècades que s'ha considerat que, de fet, implica l'entada en una nova era geològica, l'Antropocè, circumstància que, tot i ser objecte de debat encara entre els geòlegs, és acceptada com a patró d'interpretació de la realitat d'una manera cada vegada més àmplia ${ }^{13}$. En aquest context, el canvi climàtic, en la mesura que expressa la capacitat humana de transformar el Sistema Terra fins al punt del col-lapse, si més no pel que fa al manteniment de les condicions que fan possible la vida humana, sembla el cas paradigmàtic per a sostenir el relat del Antropocè, que, d'altra banda, en la mesura que es fonamenta en l'ús massiu d'energies d'origen fòssil i els seus efectes, sembla clarament superposable a l'evidència del canvi climàtic ${ }^{14}$.

Podem considerar, per tant, que el desafiament global que representa el canvi climàtic constitueix el punt adequat per plantejar-se les necessitats institucionals que implica la governança en un context planetari ${ }^{15}$. En conseqüència, els problemes i les oportunitats que aquí es susciten representen, alhora, aspectes de la necessària adaptació de la política i el dret a aquest fenomen, al mateix

perspectiva panorámica del negacionisme climàtic, vid. Riley E. Dunlap, Aaron M. McCright, "Organized Climate Change Denial", op. cit., p. 144-160.

11 Vid. Intergovernmental Panel on Climate Change, Climate Change 2014 cit., p. 48.

12 Vid. Alexandre Kiss, Dinah Shelton, Manual of European Environmental Law, Cambridge University Press. Cambridge, 1993, p. 10.

${ }^{13} \mathrm{El}$ terme 'Antropocè' va començar a circular entre la comunitat científica en el context de la recerca realitzada pel grup International Geosphere-Biosphere Programme (IGBP), a partir de 2000. Vid., en relació amb això, Paul J. Crutzen, Eugene F. Stoermer, "The «Anthropocene»", Global Change Newsletter 41, 2000, p. 17-18. Tanmateix, un dels dos autors d'aquest article,Eugene $\mathrm{F}$. Stoermer, ja l'utilitzava des de la dècada dels vuitanta, de manera més o menys informal, d'acord amb el que explica de Louis J. Kotzé, a Global Environmental Constitutionalism in the Anthropocene, Hart. Oxford, Portland, 2016, p. 32-33.

${ }^{14}$ Vid. Thomas Lowe, Katrina Brown, Suraje Dessai, Miguel de França Doria, Kat Haynes, Katharine Vincent, "Does tomorrow ever come? Disaster narrative and public perceptions of climate change", Public Understanding of Science 15(4), 2006, p. 435-457.

${ }^{15}$ Sobre la idea d'una polity, això és, una comunitat política, global en el moment present i les seves implicacions, vid. Vid. Olaf Corry, "What is a (global) polity?", Review of International Studies 36(1), 2010, p. 157-180. 
temps que àmbits de visibilitat dels canvis necessaris per adaptar els processos socials a un context de transformació antròpica del conjunt del Sistema Terra ${ }^{16}$.

Si la crisi ambiental va començar a experimentar-se en el context de la Guerra Freda, quan el relat sobre la possibilitat de transformació del Sistema Terra a partir de l'acció humana venia epitomitzada per l'ús de l'energia nuclear, el canvi climàtic esdevé, una vegada es produeix el col-lapse de la Unió Soviètica, el punt focal de les polítiques ambientals en tots els nivells i es converteix en el desafiament més significatiu que la humanitat en el seu conjunt afronta en el moment present ${ }^{17}$. Efectivament, ja no es tracta d'una situació que depengui d'un esdeveniment catastròfic puntual, sinó que la transformació antròpica es normalitza en el funcionament ordinari dels processos de reproducció social a escala global, en el context del metabolisme social de l'economia-món capitalista $^{18}$. En aquest context, el dret internacional públic ha entès que el canvi climàtic esdevé una preocupació comuna de la humanitat ${ }^{19}$.

D'altra banda, cal considerar que l'activitat humana que provoca el canvi climàtic no és homogèniament distribuïda ni pel que fa als seus causants, ni pel que fa als seus efectes ${ }^{20}$. En aquest sentit, cal contextualitzar el relat de l'Antropocè, aplicat a la descripció del canvi climàtic com a fenomen físic que transforma el Sistema Terra a partir de l'acció humana, en el context l'organització social d'aquesta acció humana, cosa que es projecta sobre la lectura que cal fer-ne a l'hora d'impulsar polítiques públiques i marcs jurídics que permetin el disseny d'una governança adaptada a aquesta nova realitat ${ }^{21}$. De manera sumària, cal considerar que el canvi climàtic, en el context de l'Antropocè, respon a l'augment

\footnotetext{
${ }^{16}$ Vid Jesse Ribot, "Cause and Response: Climate Vulnerability in the Anthropocene", Journal of Peasant Studies 41(5), 2014, p. 667-705.

17 Vid. Richard Falk, "The second cicle of ecological urgency: an environmental justice perspective", Ebbeson, Okowa, Environmental Law... cit., p. 49.

${ }_{18}$ Sobre la idea de metabolisme social i el seu origen en l'obra de Karl Marx, vid. Víctor M. Toledo, "El metabolismo social: una nueva teoría socioecológica", Relaciones 136, 2013, p. 42-43.

${ }^{19}$ Vid. Alan Boyle, "Human Rights and the Environment: Where Next?", European Journal of International Law 23(3), 2012, p. 618.

${ }^{20}$ Vid., per exemple, Marcia Rocha, Mario Krapp, Johannes Guetschow, Louise Jeffery, Bill Hare, Michiel Schaeffer, Historical Responsibility for Climate Change - from countries emissions to contribution to temperature increase, Climate Analytics, novembre 2015, disponible a $<$ http://climateanalytics.org/files/historical_responsibility_report_nov_2015.pdf> [consultat el 10 de setembre de 2018].

${ }^{21}$ En aquest sentit, cal prendre en consideració l'estructura jerarquitzada entre centre i perifèria de l'economia-món capitalista. Sobre aquesta diferenciació, vid. Peter J. Taylor, Colin Flint, Geografía política. Economía-mundo, estado-nación y localidad, Trama. Madrid, 2002 (2ª . edició castellana a càrrec de Adela Despujol Ruiz-Jiménez y Heriberto Cairo Carou), p. 21ss.
} 
del metabolisme social, això és l'intercanvi de matèria i energia entre la societat i el seu suport físic ${ }^{22}$.

L'augment del metabolisme social es produeix a partir de l'expansió de l'economia-món capitalista, un context d'intercanvi socioeconòmic, definit d'acord amb la teoria dels sistemes-món, que acaba tenint un abast planetari i que genera les condicions socials sobre les que s'opera la transformació antròpica del Sistema Terra ${ }^{23}$. L'economia-món capitalista ve configurada a través de la diferenciació entre centre i perifèria, de manera que la jerarquització de les relacions d'intercanvi provoca un flux desequilibrat de béns entre ambdós pols.

Aquest flux es descriu com a intercanvi desigual i, recentment, en termes de matèria i energia, com a intercanvi ecològicament desigual ${ }^{24}$. D'aquesta manera, el metabolisme social global definit per l'economia-món capitalista no només provoca una transformació antròpica significativa del Sistema Terra, que justifica la narrativa de l'Antropocè, sinó que ho fa en uns termes inequitatius, que fan inseparables, en acabat, les qüestions de sostenibilitat i les qüestions de justícia, que, en definitiva, defineixen la crisi civilitzatòria actual ${ }^{25}$. En aquest context, cal considerar que el canvi climàtic, en la mesura que constitueix l'expressió més conspícua de la modificació humana de la base biofísica de la reproducció social és un àmbit particularment sensible pe que fa a les qüestions de sostenibilitat $\mathrm{i}$

\footnotetext{
${ }^{22}$ Sobre l'ús del concepte de metabolisme social en el context de l'anàlisis del flux material en l'economia, vid. Marina Fischer-Kowalski, "Society's Metabolism: The Intellectual History of Materials Flow Analysis, Part I, 1860-1970", Journal of Industrial Ecology 2, 1998, p. 61-78; i Marina Fischer-Kowalski, Walter Hüttler, "Society's Metabolism: The Intellectual History of Materials Flow Analysis, Part II, 1980-1998”, Journal of Industrial Ecology 2, 1998, p. 107-136 Sobre l'augment del metabolisme social i la seva distribució desigual, vid. J. Timmons Roberts, Bradley C. Parks, "Ecologically Unequal Exchange, Ecological Debt, and Climate Justice. The History and Implications of Three Related Ideas for a New Social Movement", International Journal of Comparative Sociology 50(3-4), 2009, p. 385.

${ }^{23} \mathrm{Per}$ a un panorama general sobre el concepte de sistema-món, vid. Carlos A. Martínez-Vela, "World Systems Theory", Research Seminar in Engineering Systems, MIT, Cambridge (Mas.), 2001, <http://web.mit.edu/esd.83/www/notebook/WorldSystem.pdf> [consultat el 12 de setembre de 2018]. Aquest concepte ha estat desplegat per Immanuel Wallerstein, particularment en la seva trilogia dedicada a l'anàlis del sistema-món capitalista. Vid., particularment, Immanuel Wallerstein, El moderno sistema mundial. I. La agricultura capitalista y los orígenes de la economía-mundo en el siglo XVI, Siglo XXI. Madrid, 2010 (2ª . edició castellana a càrrec de Antonio Resines).

24 Vid. Roberts, Parks, "Ecologically Unequal Exchange..." cit.

${ }^{25}$ Vid. Andreas Malm, Alf Hornborg, "The geology of mankind? A critique of the Anthropocene narrative", The Anthropocene Review 1 (1), 2014, p. 62-69.
} 
justícia que suscita la transició cap a l'Antropocé, interpel·lant, en conseqüència, el Dret com a expressió del consens social.

\section{SOSTENIBILITAT, JUSTÍCIA CLIMÀTICA I DRETS HUMANS}

Les profundes desigualtats en l'evolució del metabolisme social que causa la transició cap a l'Antropocè es projecten particularment sobre la modificació climàtica. De fet, el règim internacional sobre el canvi climàtic expressa l'existència d'aquesta desigualtat a través del principi de responsabilitats comunes però diferenciades, del qual, si bé és cert que no s'han extret conseqüències des del punt de vista de la compensació dels perjudicats, mostra, si més no, l'existència de diferències remarcables en relació amb la causació, l'aprofitament i les conseqüències del canvi climàtic ${ }^{26}$. En aquest context, doncs, la sostenibilitat, entesa com la capacitat de reproduir indefinidament les condicions que permeten la continuïtat de la vida en el Sistema Terra, particularment, la vida humana, i la justícia, que distribuiria equitativament el gaudi d'aquestes condicions entre la comunitat humana, esdevenen elements centrals a l'hora d'articular una resposta a la problemàtica creada per la modificació antròpica del clima ${ }^{27}$.

A l'hora de vincular els conceptes de sostenibilitat i justícia en el marc de la crisi ambiental que viu la humanitat, s'ha anat desenvolupant la idea de justícia ambiental, on conflueix la problemàtica de la sostenibilitat d'un sistema fràgil i

\footnotetext{
${ }^{26}$ S'hi refereix l'art. 3 de la Convenció Marc de les Nacions Unides sobre Canvi Climàtic (CMNUCC), feta a Nova York el 9 de maig de 1992. Sobre els principis fonamentals de la CMNUCC, vid. Rudolf Dolzer, "Die internationale Konvention zum Schutz des Klimas und das allgemeine Völkerrecht", Ulrich Beyerlin, Michael Bohte, Rainer Hofmann, Ernst-Ulrich Petersmann (eds.), Recht zwischen Umbruch und Bewahrung. Festschrift für Rudolf Bernhardt, Springer. Berlin, Heidelberg, Nova York, 1995, p. 957-973. Sobre el principi particular de les responsabilitats comunes però diferenciades, vid. Jutta Brunnée, "Climate Change, global environmental justice and international environmental law", Ebbeson, Okowa, Environmental Law... cit., p. 324ss.; Stephen Clarkson, Stepan Wood, A Perilous Imbalance. The Globalization of Canadian Law and Governance, UBC Press. Vancouver, Toronto, 2009. p. 122ss.; i Miguel Ángel Elizalde Carranza, "Desarrollo y cambio climático", Revista Catalana de Dret Ambiental 1(1), 2010, p. 11-12.

${ }^{27}$ Deixaré de banda aquí la qüestió de la justícia interespecífica, que presenta problemes teòrics notables i que no és imprescindible per a l'anàlisi que segueix. En tot cas, és cert que la justícia ecològica ha anat desenvolupant-se en les dues últimes dècades com una noció teòrica i també pràctica en el context d'una visió holística de la crisi ambiental. Es tractaria d'una noció de justícia que "extends beyond human interaction to nature itself". Vid. Stephen Stec, "Environmental justice through courts in countries in economic transition", Ebbeson, Okowa (eds.), Environmental Law... cit., p. 159.
} 
limitat amb les qüestions relatives al repartiment dels efectes beneficiosos i perjudicials que genera l'acció antròpica en aquest sistema ${ }^{28}$. La justícia ambiental pretén fonamentar un repartiment equitatiu de les càrregues i els beneficis que deriven del metabolisme social, entès com intercanvi de matèria $i$ energia entre la societat i la seva base biofísica ${ }^{29}$. La justícia ambiental es va desplegar inicialment com una concepció articulada a l'entorn dels moviments socials, per esdevenir progressivament un concepte teòric que ha permès articular una resposta equitativa davant dels dèficits de distribució de l'economiamón capitalista en relació amb la utilització de les recursos naturals ${ }^{30}$.

La justícia ambiental ha estat una matriu inspiradora per altres formes de justícia que s'hi vinculen i que tenen un relleu particular en relació amb el canvi climàtic. D'una banda, cal esmentar aquí el concepte de justícia energètica, que es relaciona amb la transició energètica (Energiewende) i que, òbviament, impacta sobre l'activitat humana generadora del canvi climàtic, en la mesura que, fonamentalment, la causació antròpica del fenomen prové del model de consum energètic, particularment, l'ús massiu i inequitatiu de combustibles fòssils ${ }^{31}$. A més, s'ha desenvolupat un concepte específic de justícia climàtica que projecta la necessitat d'equitat relacionada amb la sostenibilitat de la vida en el Sistema Terra en la qüestió del canvi climàtic ${ }^{32}$. En aquest sentit, seria una faceta específica de la justícia ambiental entesa en sentit ampli.

La justícia climàtica parteix, d'una banda, de la idea de què el canvi climàtic és un fenomen intrínsecament inequitatiu i desigual, tant des del punt de vista de la responsabilitat, com des del punt de vista dels efectes ${ }^{33}$. Davant d'aquesta

\footnotetext{
${ }^{28}$ Vid., en relació amb això, Richard J. Lazarus, "Pursuing «Environmental Justice»: The Distributional Effects of Environmental Protection", Land Use and Environment Law Review, 1994, p. 263-333.

${ }^{29}$ En relació amb aquesta idea, vid. Jordi Jaria i Manzano, "Environmental Justice, Social Change and Pluralism", IUCN Academy of Environmental Law e-Journal 1, 2012, p. 18-29.

30 Sobre l'origen del concepte de justícia ambiental en els moviments socials, vid. Karin Mickelson, "Competing narratives of justice in North-South environmental relations: the case of ozone layer depletion", Ebbeson, Okowa, Environmental Law... cit., p. 300.

${ }^{31}$ Sobre l'Energiewende, vid. Anaïs Guerry, "A reflection on some legal aspects of decision control in the energy transition process: a comparison of France and Germany", Jordi Jaria i Manzano, Nathalie Chalifour, Louis J. Kotzé (eds.), Energy, Governance and Sustainability, Edward Elgar. Cheltenham, Northampton, 2016, p. 194ss.

${ }^{32}$ Sobre la relació entre la justícia ambiental i la justícia climàtica, vid. Brunnée, "Climate Change..." cit. Sobre el concepte de justícia climàtica, vid. Stephen M. Gardiner, "Climate Justice", Dryzek, Norgaard, Schlosberg, The Oxford Handbook... cit., p. 309-322.

${ }^{33}$ Vid. Will Steffen, "A Truly Complex and Diabolical Policy Problem", Dryzek, Norgaard, Schlosberg, The Oxford Handbook... cit., p. 23-24.
} 
realitat, pren en consideració que la dignitat de la persona no es pot realitzar plenament quan les condicions climàtiques impedeixen el desenvolupament d'una vida humana sana, això és, les conseqüències de la desigualtat climàtica en relació amb la protecció de les persones ${ }^{34}$. D'aquesta manera, estableix un vincle amb els drets humans "to achieve a human-centred approach, safeguarding the rights of the most vulnerable people and sharing the burdens and benefits of climate change and its impacts equitably and fairly"35. De fet, aquest vincle amb els drets humans ha estat subratllat en l'àmbit de les Nacions Unides, la qual cosa permet articular la matriu bàsica per fonamentar la litigació climàtica. En concret, l'Oficina de l'Alt Comissionat de Nacions Unides per als Drets Humans (OACNUDH) ha posat de manifest que, en relació amb el canvi climàtic, cal tenir en compte els següents aspectes en matèria de drets humans:

- To mitigate climate change and to prevent its negative human rights impacts.

- To ensure that all persons have the necessary capacity to adapt to climate change.

- To ensure accountability and effective remedy for human rights harms caused by climate change.

- To mobilize maximum available resources for sustainable, human rightsbased development.

- International cooperation.

- To ensure equity in climate action.

- To guarantee that everyone enjoys the benefits of science and its applications.

- To protect human rights from business harms.

- To guarantee equality and non-discrimination.

- To ensure meaningful and informed participation ${ }^{36}$.

\footnotetext{
${ }^{34}$ Sobre la idea de la dignitat en aquest context, vid. Gregorio Mesa Cuadros, "Elementos para una teoría de la justicia ambiental", Gregorio Mesa Cuadros (ed.), Elementos para una teoría de la Justicia Ambiental y el Estado Ambiental de Derecho, Universidad Nacional de Colombia. Bogotá, 2011, p. 31.

35 Mary Robinson Foundation, "Principles of Climate Justice", disponible a $<$ https://www.mrfcj.org/principles-of-climate-justice/> [consultat el 7 de juny de 2018].

36 Vid. OHCHR's Key Messages on Human Rights and Climate Change, disponible a <http://www.ohchr.org/EN/lssues/HRAndClimateChange/Pages/HRClimateChangelndex.aspx> [consultat el 16 de juny de 2018].
} 
Amb aquestes consideracions es fa transparent la importància del canvi climàtic a l'hora de construir un context apropiat de convivència i la seva projecció en la substància axiològica fonamental del sistema de Nacions Unides. Si hom considera que els drets humans es projecten, a partir del seu reconeixement en la Declaració Universal, com l'element fonamental del constitucionalisme global, les observacions de l'OACNUDH poden servir per començar a articular un discurs en el que, efectivament, es puguin sostenir demandes de contingut climàtic a partir de les previsions constitucionals dels diferents estats, la qual cosa obre la porta a la litigació climàtica, que és allò que aquí ens interessa ${ }^{37}$.

\section{LA LITIGACIÓ CLIMÀTICA: UN PANORAMA GENERAL}

Fa més d'una dècada Myles R. Allen i Richard Lord posaven de manifest que l'exigència de responsabilitat en relació amb els efectes de les emissions de GEH havia estat un tabú en el debat sobre el canvi climàtic. Tanmateix, en opinió d'aquests autors, calia ser conscients de què hi havia persones que ja estaven pagant els costos d'adaptació al canvi climàtic, de manera que, segons el seu criteri, l'aspecte crític per a una bona part de la humanitat en relació amb aquesta qüestió era la identificació dels responsables d'assumir els esmentats costos d'adaptació, així como la compensació a aquelles persones que es troben en una situació que fa impossible l'adaptació ${ }^{38}$.

En aquest context, sembla clar que la litigació climàtica ha de jugar un paper crucial, canalitzant les demandes relatives a l'exigència de responsabilitats, que han de proporcionar els fons per a les polítiques d'adaptació, al mateix temps

\footnotetext{
${ }^{37}$ El constitucionalisme global és una narrativa que pretén establir un patró d'interpretació del dret internacional en el context de la globalització, tot insistint en les seves característiques constitucionals, fonamentalment en relació amb els drets humans, i la interconnexió dels diversos sistemes jurídics a partir d'uns fonaments compartits. Vid. Anne Peters, "Global Constitutionalism", Michael Gibbons (ed.), The Encyclopedia of Political Thought, WileyBlackwell. Bognor Regis, 2015, p. 1-4. En el context de l'Antropocè, la idea del constitucionalisme global es vincula a la crisi ambiental global i adquireix relleu en relació amb qüestions com ara el canvi climàtic. Vid. Louis J. Kotzé, "Arguing Global Environmental Constitutionalism", Transnational Environmental Law 1, 2012, p. 199. En aquest sentit, a l'hora de considerar la litigació climàtica, és molt útil configurar-la en el context d'un marc constitucional complex, que permet integrar el dret internacional i, particularment, els drets humans a l'hora de construir la posició jurídica dels demandants, connectant-la amb les disposicions constitucionals internes per desenvolupar estratègies de control i exigència de responsabilitats en la construcció de les respostes a la transformació antròpica del Sistema Terra que dona lloc al canvi climàtic.

${ }^{38}$ Vid. Myles R. Allen, Richard Lord, "The blame game", Nature 432, 2004, p. 551.
} 
que han de desincentivar les polítiques i les activitats que causen el canvi climàtic això és, ha de proporcionar canals adequat del control de les decisions que determinen l'empremta antròpica sobre el clima. D'entrada, en relació amb les possibilitats de la litigació climàtica pel que fa tant a l'exigència de responsabilitats com al control del poder en aquest context, cal remarcar que s'ha desenvolupat un marc normatiu considerable en relació amb el canvi climàtic, que abasta des dels acords internacionals a partir de la Convenció contra el canvi climàtic, completada darrerament amb l'Acord de París, fins a les diverses regulacions estatals o infraestatals relatives a aquesta qüestió, la qual cosa permet als litigants l'ús d'aquestes normes per avaluar l'adequació o inadequació dels esforços dels poders públics en matèria climàtica ${ }^{39}$.

Entre la multitud de casos que s'han anat plantejant en els darrers anys, n'hi ha dos que han adquirit significació especial i que poden considerar-se leading cases en la matèria. D'una banda, cal esmentar el cas Urgenda, en el qual la ciutadania, a través d'una organització no governamental, ha pogut exigir responsabilitats al seu govern en relació al que ha estat considerat una actuació insuficient per protegir-la dels efectes negatius del canvi climàtic ${ }^{40}$. En un primer moment, la decisió del Tribunal de Districte de la Haia del 24 de juny de 2015 va considerar que el Govern neerlandès havia de prendre les mesures oportunes per reduir les emissions dels Països Baixos pel cap baix un $25 \%$ en comparació als nivells de 1990 cap al final de $2020^{41}$.

En conseqüència, ens trobem davant de la decisió d'un tribunal de justícia que commina el Govern a prendre mesures efectives en relació amb el canvi climàtic i, per tant, assenyala un camí per exigir no només responsabilitats, sinó també accions efectives per part dels poders públics en aquest àmbit. Tanmateix, al setembre de 2015, malgrat l'oposició manifestada no només pels demandants, sinó també per membres de la comunitat científica i ciutadans en general, el Govern neerlandès va recórrer la decisió. Finalment, el 9 d'octubre de 2018, el

\footnotetext{
39 United Nations Environment Programme, The Status of Climate Change Litigation - A Global Review, 2017, p. 4.

40 La informació sobre el cas està disponible a <http://www.urgenda.nl/en/climate-case/> [consultat el 10 de juliol de 2018].

41 El veredicte del Tribunal està disponible a <http://www.urgenda.nl/wpcontent/uploads/VerdictDistrictCourt-UrgendavStaat-24.06.2015.pdf> [consultat el 18 de setembre de 2018].
} 
Tribunal d'Apel·lació de la Haia va validar la decisió de l'òrgan d'instància, donant lloc al que es considera com una decisió de transcendència històrica, que sembla que permet concebre esperances en relació amb l'impacte de les decisions dels tribunals de justícia en relació amb el control de les polítiques climàtiques i l'exigència de responsabilitats en aquest àmbit ${ }^{42}$.

Un altre leading case, ara a la jurisdicció federal nordamericana, és Juliana. Consisteix en una demanda presentada per una sèrie de joves contra el Govern dels Estats Units davant de la Cort de Districte d'Oregon l'any 2015, en la que també pren part l'organització Earth Guardians, demanda que va ser admesa a tràmit el 2016 en una decisió interlocutòria que acceptava la legitimitat activa dels demandants ${ }^{43}$. La demanda considera que les accions realitzades pel Govern federal que contribueixen al canvi climàtic constitueixen una violació dels drets a la vida, la llibertat i la propietat de les generacions més joves, així com una falta al deure de cura en relació amb els recursos confiats al Govern ${ }^{44}$.

Si, en el cas Urgenda, la dimensió constitucional resta implícita en una demanda civil, que, en realitat, parteix del dret d'immissions, en el cas de Juliana, aquesta dimensió és plenament explícita, tot lligant les polítiques ineficaces i, fins i tot, estimuladores del canvi climàtic a la violació drets constitucionals, la qual cosa, en definitiva, dibuixa un escenari en què la justícia climàtica, lligada al gaudi dels drets humans, pot trobar un recorregut en l'àmbit de la litigació a través de les normes constitucionals d'un determinat sistema jurídic.

La importància d'aquesta demanda, però, ha donat lloc a un capteniment, qualificat d'obstruccionista per part dels demandants, de l'Administració Trump adreçat a posar les màximes dificultats possibles per a la seva tramitació, particularment, mitjançant objeccions de caràcter processal substanciades davant de la Novena Cort d'Apel-lació, el pronunciament de la qual era determinant per a què que el cas avancés davant de la Cort de Districte, on la

42 Una traducció no oficial a l'anglès de la decisió en apel·lació està disponible a <https://www.urgenda.nl/wp-content/uploads/ECLI_NL_GHDHA_2018_2610.pdf> [consultat el 24 d'octubre de 2018].

${ }^{43}$ Vid. Juliana v. United States, No. 6:15-CV-01517-TC, 2016 WL 6661146 (D. Or. Nov. 10, 2016), disponible a <https://biotech.law.Isu.edu/cases/environment/Juliana.htm> [consultat el 19 de setembre de 2018].

${ }^{44}$ La informació sobre el cas és accessible a <https://www.ourchildrenstrust.org/us/federallawsuit/> [consultat el 20 de juliol de 2018]. 
demanda havia estat presentada ${ }^{45}$. Finalment, però, la Novena Cort d'Apel·lació va decidir, el 7 de març de 2018, rebutjar el writ of mandamus presentat pel Govern federal, de manera que el judici ha estat fixat per al dia 29 d'octubre de $2018^{46}$.

Sigui com sigui, aquests dos casos mostren les possibilitats processals per part de persones afectades pel canvi climàtic o d'organitzacions que s'ocupen de la qüestió de traslladar el debat sobre les polítiques adoptades en aquesta matèria a l'àmbit dels tribunals. En aquest sentit, la litigació climàtica és una porta oberta per a la fiscalització dels poders públics, en moltes ocasions poc proclius a adoptar polítiques efectives de mitigació i adaptació davant del canvi climàtic, així com, de manera paral-lela, per a l'exigència de responsabilitats en relació amb els efectes del fenomen. Aquests dos aspectes configuren el sentit de la litigació climàtica. Vegem tot seguit quines expectatives genera el Tribunal Constitucional espanyol en relació amb això, a partir de pronunciaments previs relatius a les polítiques energètiques.

\section{CONTROL I RESPONSABILITAT EN LA PROTECCIÓ DEL MEDI AMBIENT: LA POSICIÓ DEL TRIBUNAL CONSTITUCIONAL}

La litigació climàtica afronta una situació en la que es produeix, per dir-ho d'alguna manera, un desplaçament des de la regulació a la litigació a causa de la captura del legislador, que genera normatives favorables a les grans corporacions i desincentiva les polítiques actives de transició energètica, cosa que, per altra banda, també pot projectar-se en relació amb la posició internacional dels estats, en un context de dependència dels mercats per obtenir el finançament que permet les polítiques públiques sobre les que fan reposar la seva legitimació ${ }^{47}$. Per reconduir aquesta situació, sembla raonable pensar en la possibilitat d'impulsar accions davant dels jutges i tribunals amb l'objecte d'obtenir resolucions que puguin obligar a fer canvis significatius en les polítiques seguides pels poders públics representatius, com es pot veure en el casos

\footnotetext{
${ }^{45}$ Aquesta informació també està disponible al lloc esmentat.

${ }^{46}$ En el moment de tancar aquestes pàgines, la decisió de la Cort de Districte encara no havia estat adoptada.

47 Vid. Joseph Stiglitz, The Price of Inequality, Norton. Nueva York, Londres, 2013, p. 174.
} 
Urgenda i Juliana, als que m'acabo de referir. En aquest sentit, com posen de manifest Allen i Lord, "[u]ntil now, most of the legal focus has been on regulations, but litigation in relation to greenhouse-gas emissions is increasingly likely, and has already started"48.

Efectivament, les polítiques que tenen incidència en el canvi climàtic s'articulen a través d'una legislació que pot arribar a oferir un tracte de privilegi als actors corporatius, més enllà dels fenòmens de porta giratòria, a causa de la pressió dels mercats de capital, que constitueixen la font de finançament dels estats, la qual cosa dona lloc a la captura del regulador, particularment, en àmbits com l'energètic, on la incidència sobre el clima i la capacitat d'influència del sector empresarial són molt notables ${ }^{49}$. En aquest sentit, la litigació apareix com un instrument de control dels poders públics, els quals, en un context notori de dependència, tenen incentius molt notoris per continuar amb polítiques que tenen un impacte negatiu en el clima, entre altres mesures regressives en matèria ambiental, que s'han agreujat amb la crisi econòmica del $2008^{50}$.

D'altra banda, la litigació climàtica no només es projecta sobre el control del poder, particularment, dels poders públics, sinó que també té una incidència en l'exigència de responsabilitat, essent ambdós fenòmens, de fet, les dues cares de la mateix moneda. En realitat, l'exigència de responsabilitats en el context de la causació del canvi climàtic és el correlat natural del control del poder en un escenari de polítiques energètiques sota pressió dels actors corporatius menys interessats en estratègies de menor impacte ${ }^{51}$.

\footnotetext{
${ }^{48}$ Vid. Allen, Lord, "The blame game" cit., p. 552.

${ }^{49}$ Vid. Jordi Jaria i Manzano, "Constitución, desarrollo y medio ambiente en un contexto de crisis", Revista Catalana de Dret Ambiental 8(1), 2017, p. 23.

${ }^{50}$ Per al cas d'Espanya, vid. Alba Nogueira López, Susana Borràs Pentinat, Rosa Giles Carnero, Jordi Jaria Manzano, "Marco general. El medio ambiente en los tiempos de globalización neoliberal", Francisco Javier Sanz Larruga, J. José Pernas García (dirs.), Jennifer Sánchez (coord.), Derecho ambiental para una economía verde. Informe ECOVER, Thomson ReutersAranzadi. Cizur Menor, 2016, p. 21-48.

${ }^{51}$ En relació amb l'exigència de responsabilitats en un context d'incidència manifesta de les grans corporacions empresarials no només en la determinació de les polítiques climàtiques, sinó en la pròpia causació del canvi climàtic, cal tenir en compte la necessària projecció en aquest àmbit de l'eficàcia horitzontal dels drets fonamentals (Drittwirking der Grundrechte). En relació amb la virtualitat d'aquest marc conceptual per respondre a les violacions dels drets humans per part de les empreses multinacionals, a les que no són alienes les situacions de vulnerabilitat creades pel canvi climàtic, vid. Jordi Jaria i Manzano, "Consideraciones constitucionales en relación con la protección de las víctimes de violacions de los derechos humanos causades por la actividad de las empresas españolas en el extranjero", Maria Chiara Marullo, Francisco Javier Zamora Cabot
} 
La problemàtica de l'exigència de responsabilitats és múltiple. D'una banda, cal anotar la complexitat a l'hora d'establir cadenes causals clares entre determinades conductes o decisions i la causació efectiva del canvi climàtic ${ }^{52}$. El dret tal com el coneixem, doncs, presenta insuficiències conceptuals notòries, en la mesura que aplica esquemes cartesiano-newtonians a una realitat que el coneixement hegemònic mateix —això és, la tecnociència - interpreta a partir d'altres patrons, fonamentalment, la física relativista i la mecànica quàntica ${ }^{53}$. Des d'aquest punt de vista, un dels problemes crucials en l'àmbit del dret ambiental, que adquireix una dimensió especialment significativa en matèria de canvi climàtic és la construcció de la veritat processal i els problemes que s'associen amb la prova ${ }^{54}$.

D'altra banda, cal notar que les dinàmiques internes del sistema tendeixen a fer una distribució esbiaixada de la responsabilitat, de manera que, tot sovint, és la ciutadania, a través dels impostos, la que assumeix els costos de decisions o conductes que depenen d'actors privats o els beneficis de les quals corresponen a actors privats. En el cas espanyol, cal esmentar el cas Cástor. En aquest supòsit, es planteja la qüestió de qui ha d'assumir la responsabilitat de la inversió feta per una prospecció gasística una vegada s'ha d'interrompre per causa de l'aflorament de riscos sísmics no previstos inicialment. El cas va ser resolt pel Tribunal Constitucional en la STC 152/2017, de 21 de desembre ${ }^{55}$. La decisió del Tribunal responia al recurs d'inconstitucionalitat plantejat contra el Reial Decretllei 13/2014, de 3 d'octubre, mitjançant el qual s'adopten mesures urgents en relació amb el sistema gasista i la titularitat de les centrals nuclears ${ }^{56}$. Es referia,

(eds.), Empresas y derechos humanos. Temas actuales, Editoriale Scientifica. Nàpols, 2018, p. 69-89.

52 Vid. Anne Petitpierre-Sauvain, "La responsabilité du polleur: révision de la LPE et droit souhaitable", La semaine judiciaire 2, 1996, p. 22.

${ }^{53}$ Això du a lloc a la incertesa estructural de la informació disponible, que ve paradigmàticament enunciada en el principi d'indeterminació de Heisenberg, d'acord amb el qual la precisió en la determinació de la posició d'una partícula subatòmica és inversament proporcional a la precisió en la determinació de la seva massa i velocitat. Vid., en relació amb això, Roger Penrose, La nueva mente del emperador, Grijalbo-Mondadori. Barcelona, 1991 (edición castellana de Javier García Sanz), p. 314ss. En el plànol macroscòpic, la complexitat del Sistema Terra dona lloc també a una situació d'incertesa en relació amb les cadenes causals. Vid. Kenneth A. Manaster, "Law and the Dignity of Nature: Foundations of Environmental Law", Land Use and Environment Law Review, 1978, p. 16ss.

${ }^{54}$ Vid. Stephen Humphreys, "Competing claims: human rights and climate harms", Humphreys, Human Rights... cit., p. 52.

${ }^{55}$ BOE núm. 15, de 17 de gener de 2018.

${ }^{56}$ BOE núm. 241, de 4 d'octubre de 2014. 
en particular, a les mesures preses pel Govern en relació amb la renúncia la concessió de l'explotació per part de la societat concessionària ${ }^{57}$.

La Sentència considera apropiada la hibernació del projecte a través del Decretllei discutit, però, en canvi, determina que els efectes que es preveuen en relació amb l'extinció de la concessió van més enllà d'allò que és constitucionalment admissible, en la mesura que la situació de necessitat urgent i extraordinària que justifica la finalització de les operacions no cobreix, en canvi, els efectes determinats pel Govern. Ara bé, més enllà de la idoneïtat de la utilització del decret-llei en aquest cas, la decisió del Tribunal no entra a considera les qüestions materials relatives a la responsabilitat $i$, per tant, a la determinació de qui ha d'assumir el cost de les indemnitzacions derivats de l'extinció de la concessió; en definitiva, qui assumeix el risc, cosa que el Decret-llei resolia tot atribuint-lo a l'Estat i, per tant, en última instància, a la ciutadania ${ }^{58}$.

En relació amb això, Julio González García assenyala que "[r]esulta muy paradójico que no sea el concesionario [qui assumeixi la responsabilitat], ni total ni parcialmente, a pesar que su vinculación con la zona proviene de 1996, esto es, ocho años antes de que aparecieran los problemas. Es especialmente curioso el hecho de que la sentencia del Tribunal Supremo que resolvió uno de los recursos planteados en esta materia, ya se señalaba el hecho de que la responsabilidad del concesionario era previsible" 59 . Aquest cas, mostra, al meu entendre, que el marc hermenèutic que defineix el Tribunal Constitucional és poc prometedor des del punt de vista de l'exigència de responsabilitat en relació amb la mitigació i l'adaptació del canvi climàtic. Aquest és un factor desincentivador en relació amb la practicabilitat de la litigació climàtica a Espanya, particularment pel que fa a les empreses responsables del gruix de les emissions de GEH. Tanmateix, això no exclou, en principi, la possibilitat d'exigir responsabilitats als actors que contribueixen a la producció del canvi climàtic, la qual cosa pot

\footnotetext{
${ }^{57}$ Arts. 4 a 6 del Reial-Decret llei 13/2014.

58 Vid. un comentari de la Sentència a Jordi Jaria i Manzano, "Jurisprudencia constitucional en materia de protección del medio ambiente (primer semestre 2018)", Revista Catalana de Dret Ambiental, 9(1), 2018, p. 8ss.

${ }^{59}$ Vid. Julio González García, "STC 152/2017, sobre el caso Castor: un problema jurídica, social y políticamente inacabado", Blog de la Revista Catalana de Dret Públic, 1 de febrer de 2018, disponible a <http://eapc-rcdp.blog.gencat.cat/2018/02/01/stc-152-2017-sobre-el-caso-castorun-problema-juridica-social-y-politicamente-inacabado-julio-gonzalez-garcia/> [consultat el 20 de juliol de 2018].
} 
vehicular-se a través de la jurisdicció civil, així també en l'àmbit de la jurisdicció contenciosa administrativa -i també davant del Tribunal Constitucional-, en la mesura que aquesta responsabilitat derivi de les decisions dels poders públics.

La dimensió pública de la responsabilitat en aquest àmbit és important, atesa la incidència de les polítiques energètiques en a l'hora de definir les condicions en què els operadors privats produeixen l'energia i, per tant, els estímuls que existeixen en relació amb l'emissió de $\mathrm{GEH}^{60}$. Aquí sorgeix, per tant, la qüestió del control del poder polític i de la fiscalització de l'activitat administrativa. Tanmateix, cal admetre que, en relació amb el control de les polítiques públiques relacionades amb la causació del canvi climàtic, aspecte fonamental en els leading cases citats més amunt —Urgenda i Juliana- la jurisprudència constitucional tampoc no convida a l'optimisme ${ }^{61}$. Hi dos aspectes crucials en relació amb la política energètica espanyola en què el Tribunal Constitucional ha pogut pronunciar-se en un sentit que tingués en compte els seus efectes sobre el canvi climàtic i, per tant, en relació amb la dimensió constitucional de la qüestió, cosa que hauria significat l'establiment d'uns paràmetres constitucionals per enquadrar la possibilitat i la projecció de la litigació climàtica.

D'una banda, cal referir-se a la jurisprudència constitucional sobre la fractura hidràulica (fracking). El desenvolupament d'aquesta tecnologia per a l'obtenció d'energia ha generat posicionaments polítics divergents en relació amb el seu ús. Particularment, en el cas espanyol, diferents comunitats autònomes han decidit legislar per prohibir o limitar severament l'ús d'aquesta tècnica, que consisteix, fonamentalment, en la injecció d'aigua a alta pressió — barrejada amb altres productes- amb la finalitat de provocar una fractura en la formació rocosa que conté gas d'esquist, un hidrocarbur atrapat en la mateixa roca, de manera que aflori a la superfície i pugui ser utilitzats com a combustible ${ }^{62}$.

\footnotetext{
${ }^{60}$ Cal esmentar aquí, particularment, la Llei 24/2013, de 26 de desembre, del Sector Elèctric (BOE núm. 310, de 27 de desembre de 2013); i la Llei 34/1998, de 7 de octubre, del sector d'hidrocarburs (BOE núm. 241, de 8 d'octubre de 1998; modificada en diverses ocasions des d'aleshores).

${ }^{61}$ En general, sobre això, vid. Jaria i Manzano, "Constitución..." cit., p. 23ss.

62 Vid. Alejandra Martins, “¿Qué es el fracking y por qué genera tantas protestas?”, BBC, 29 d'octubre de 2013, disponible a $<$ https://www.bbc.com/mundo/noticias/2013/10/131017_ciencia_especial_fracking_abc_am> [consultat l'1 d'octubre de 2018].
} 
A partir d'aquí, el Tribunal Constitucional s'ha pronunciat en una sèrie de sentències, concretament, les 106/2014, de 24 de juny ${ }^{63} ; 134 / 2014$, de 22 de juliol ${ }^{64}$; 208/2014, de 15 de desembre ${ }^{65}$; i STC 260/2015, de 3 de desembre ${ }^{66}$. En aquests pronunciaments, el Tribunal, fonamentalment, ha evitat entrar en el fons de la qüestió i, pronunciar-se, en particular, sobre els riscos que aquesta tecnologia implica, tant de del punt de vista de la salut humana (art. $43 \mathrm{CE}$ ) com des del punt de vista de la protecció del medi ambient (art. $45 \mathrm{CE})^{67}$. No cal dir que, si això és així, el Tribunal ni tan sols es planteja els efectes de l'ús d'aquesta tecnologia des del punt de vista de la generació de GEH i, per tant, la seva contribució al canvi climàtic. Amb aquests pronunciaments, el Tribunal Constitucional es mostra absolutament aliè a la problemàtica del canvi climàtic i, en conseqüència, és incapaç d'interpretar-la en termes constitucionals.

Aquesta impressió es referma en contemplar la jurisprudència constitucional sobre el canvi de l'estratègia energètica del Govern, consistent fonamentalment a revertir la política de foment de les energies renovables i, en conseqüència, reforçar la presència d'energies fòssils en l'oferta, amb les conseqüències previsibles des del punt de vista de l'augment de les emissions de GHE, de manera que es promou una regressió clara en relació amb la mitigació del canvi climàtic. Ens trobem aquí també davant d'una sèrie de sentències, entre les cal destacar la 96/2014, de 12 de juny68; la 109/2014, de 26 de juny ${ }^{69}$; la 270/2015, de 17 de desembre ${ }^{70}$; la 19/2016, de 4 de febrer ${ }^{71}$; la 29/2016, de 18 de febrer ${ }^{72}$; la 30/2016, de 18 de febrer ${ }^{73}$; i la 42/2016, de 3 de març $^{74}$.

En aquesta sèrie de sentències, el Tribunal Constitucional renuncia a entrar en el fons de les qüestions litigioses, atès que la volatilitat normativa del sector fa

\footnotetext{
${ }^{63}$ BOE núm. 177, de 27 de juliol de 2014.

${ }^{64}$ BOE núm. 199, de 16 d'agost de 2014.

${ }^{65}$ BOE núm. 17, de 20 de gener de 2015.

${ }^{66}$ BOE núm. 10, de 12 de gener de 2016.

67 El vot particular a la STC 106/2014, de 24 de juny, subscrit pels magistrats Valdés Dal-Ré, Xiol Ríos y Asua Batarrita, assenyala que el Tribunal "no pondera debidamente la incidencia de los riesgos del 'fracking' en un interés de la máxima relevancia constitucional como es la protección de la salud humana".

${ }^{68}$ BOE núm. 162, de 4 de juliol de 2014.

${ }^{69}$ BOE núm. 177, de 22 de juliol de 2014.

${ }^{70}$ BOE núm. 19, de 22 de gener de 2015.

${ }^{71}$ BOE núm. 57, de 7 de març de 2016.

72 BOE núm. 71, de 23 de març de 2016.

${ }^{73}$ BOE núm. 71, de 23 de març de 2016.

${ }^{74}$ BOE núm. 85, de 8 d'abril de 2016.
} 
que els seus pronunciaments es dictin, majorment, quan la norma analitzada ja ha perdut vigència, de manera que, virtualment, s'absté d'exercir el control de constitucionalitat en matèria energètica ${ }^{75}$. En conseqüència, sembla que una visió panoràmica de la jurisprudència constitucional relacionada amb el Dret de l'energia és més aviat descoratjadora a l'hora de proporcionar un punt de suport per a construir casos viables de litigació climàtica. Malgrat això, potser val la pena explorar la possibilitat d'articular uns paràmetres constitucionals de control més consistents i eficaços. Cal, en definitiva, tornar al text de la Constitució i provar de veure si se'n poden desplegar patrons per a l'argumentació jurídica en relació amb el canvi climàtic.

\section{VI. 'BACK TO BASICS': LA CONSTITUCIÓ ESPANYOLA I LES PERSPECTIVES DE LA LITIGACIÓ CLIMÀTICA A ESPANYA}

L'article $45 \mathrm{CE}$ de la Constitució espanyola és més promissori, al meu entendre, que allò que l'ús que n'ha fet el Tribunal Constitucional històricament pugui fer pensar. Així, en relació amb els dos aspectes essencials que es despleguen en relació amb la litigació climàtica, el text de la disposició esmentada, permet establir una matriu que una interpretació més progressiva i ambiciosa de la Constitució podria permetre desplegar a l'hora de construir estratègies de control en relació amb les polítiques climàtiques, cosa que, fonamentalment, afecta a la mitigació, i avançar en l'exigència de responsabilitats en relació amb la causació del canvi climàtic, cosa que afecta, sobretot, al finançament de les accions d'adaptació. Així, més enllà del dret reconegut en l'article 45.1 CE, cal referir-se a allò que es preveu en l'apartat segon del mateix article, disposició que, en la meva opinió, és un punt de partida per fundar accions de control de les polítiques públiques relatives al canvi climàtic. En concret, l'article 45.2 CE estableix:

Los poderes públicos velarán por la utilización racional de todos los recursos naturales, con el fin de proteger y mejorar la calidad de la vida y defender $y$ restaurar el medio ambiente, apoyándose en la indispensable solidaridad colectiva.

\footnotetext{
${ }^{75}$ Vid. Jordi Jaria i Manzano, "Jurisprudencia constitucional en materia de protección del medio ambiente (Segundo semestre 2014)”, Revista Catalana de Dret Ambiental 5(2), 2014, p. 12.
} 
Estableix, doncs, una obligació dels poders públics que cal estendre a l'ús dels combustibles fòssils, en la mesura que això afecta a la composició de l'atmosfera, que cal considerar un recurs natural en el sentit de l'article 45.2 CE, així com, indirectament a altres recursos naturals, la configuració i la disponibilitat dels quals es veuria afectada pel canvi climàtic. Es planteja, com és habitual, la justiciabilitat de l'article $45 \mathrm{CE}$, que ha estat exclosa en ocasions per la doctrina dominant, en base a les previsions de l'article 55.3 CE. Tanmateix, sóc de l'opinió que el dret a un medi ambient adequat en la Constitució es concreta, en combinació amb la previsió continguda a l'apartat segon de l'article $45 \mathrm{CE}$, en la possibilitat d'exigir als poders públics "el respeto a los límites constitucionales en relación con su facultad de configuración del medio ambiente protegido, de modo que, efectivamente, cumpla con la finalidad que la propia Constitución fija, esto es, la adecuación al desarrollo de la persona"76.

Per tant, en conseqüència, considero que és possible induir el control del legislador en matèria de canvi climàtic i discutir constitucionalment l'acceptabilitat de determinades polítiques públiques, legislativament formulades, en atenció als seus efectes sobre el clima -en la mesura que emparen o afavoreixen una utilització dels recursos naturals— ${ }^{77}$. En aquest sentit, entenc que, quan l'article 53.3 CE estableix que "[e]l reconocimiento, el respeto y la protección de los principios reconocidos en el Capítulo tercero informarán la legislación positiva, la práctica judicial y la actuación de los poderes públicos”, de manera que només "podrán ser alegados ante la Jurisdicción ordinaria de acuerdo con lo que dispongan las leyes que los desarrollen", no exclou el control de constitucionalitat, cosa que seria tant com negar la normativitat d'una part del text constitucional ${ }^{78}$.

\footnotetext{
76 Vid. Jordi Jaria i Manzano, "Derechos y medio ambiente", Albert Noguera Fernández, Adoración Guamán Hernández, Lecciones sobre Estado social y derechos sociales, Tirant lo Blanch. Valencia, 2014, p. 596.

77 Vid. Nicolai Müller-Bromley, Staatszielbestimmung Umweltschutz im Grundgesetz? Rechtsfragen der Staatszielbestimmung als Regelungsform der Staatsaufgabe Umweltschutz, Eric Schmidt. Berlín, 1990, p. 117.

${ }^{78}$ En relació amb la justiciabilitat de l'article $45 \mathrm{CE}$, vid. Ramón Martín Mateo, Tratado de Derecho Ambiental (I), Trivium. Madrid, 1991. En relació amb el control de constitucionalitat a partir del capítol III del Títol I de la Constitució espanyola, vid. Enoch Albertí Rovira, Autonomía política y unidad económica, Civitas. Madrid, 1995, p. 209; i José María Porras Ramírez, "Caracterización y garantía de los derechos de prestación en el Estado constitucional", Francisco Balaguer Callejón, Derecho constitucional y cultura. Estudios en homenaje a Peter Häberle, Tecnos. Madrid, 2004, p. 669. En relació al valor normatiu del conjunt del text de la Constitució espanyola,
} 
En la meva opinió, efectivament, l'article $45 \mathrm{CE}$ i, en el cas que ens ocupa, particularment l'apartat segon, pot ser utilitzat per fer efectiu el control de normes, encara que calgui entendre, d'acord amb l'article 53.3 CE que no permet sostenir pretensions jurídiques subjectives associades a una prestació concreta dels poders públics ${ }^{79}$. En aquest sentit, crec que es pot avançar considerablement més del que ho ha fet el Tribunal Constitucional en relació amb el control de les polítiques energètiques $\mathrm{i}$, en general, de les polítiques que tenen incidència en el canvi climàtic. Per a això, cal, en definitiva, prendre's seriosament l'article 45 CE com a paràmetre de constitucionalitat i construir una argumentació persuasiva que permeti establir fermament que una determinada decisió del legislador, en la mesura que contribueix a l'agreujament del canvi climàtic, valida una utilització irracional dels recursos naturals $\mathrm{i}$, en última instancia, lesiona el dret a un medi ambient adequat per al desenvolupament de la persona ${ }^{80}$.

Pel que fa a l'exigència de responsabilitats, tot i que la seva canalització a través de la justícia constitucional no és tan transparent, cal admetre que, en tot cas, un règim jurídic de les responsabilitats en relació amb l'assumpció dels costos de l'adaptació al canvi climàtic ha de partir, així mateix, d'una base constitucional. En aquest sentit, en relació amb les responsabilitats que puguin derivar-se en relació amb les conseqüències de l'ús dels combustibles fòssils sobre el sistema climàtic, cal tenir en compte els beneficis obtinguts de la seva explotació comercial i del seu ús industrial, la qual cosa implica la incorporació de les externalitats al sistema de $\operatorname{costos}^{81}$. El marc constitucional en relació amb

vid. Raúl Canosa Usera, Interpretación constitucional y fórmula política, Centro de Estudios Constitucionales. Madrid, 1988, p. 60.

79 Vid. Eduardo García de Enterría, La Constitución como norma y el Tribunal Constitucional, Civitas, Madrid, 1985 (3a. edició), p. 69; i Agustín Ruiz Robledo, "Un componente especial de la Constitución económica: La protección del medio ambiente", Revista Andaluza de Administración Pública 14, 1993, p. 35.

${ }^{80}$ En aquest sentit, li correspon al Tribunal Constitucional construir una argumentació persuasiva que sigui representativa del conjunt de la ciutadania com a titular de la sobirania (article 1.2 CE) i corregeixi la decisió de la institució democràtica representativa sobre la base de la necessitat de restaurar la virtualitat del pacte constituent, que limita les opcions del legislador democràtic. Vid., en aquest sentit, Robert Alexy, "Los derechos fundamentales en el Estado constitucional democrático", Miguel Carbonell, (ed.), Neoconstitucionalismo(s), Trotta, Madrid, 2003, p. 40.

${ }^{81}$ Sobre aquesta qüestió, amb caràcter general, vid. Jordi Jaria i Manzano, "La externalización de costes ambientales en el acceso a los recursos naturales: marco institucional y distribución inequitativa", Proyecto "Del desarrollo sostenible a la justicia ambiental: Hacia una matriz conceptual para la gobernanza global" (DER2013-44009-P), informe núm. 4, 2016, $<$ http://www.dret-

public.urv.cat/media/upload/domain_89/arxius/working\%20papers/DEFINITIUS/working\%20pap er\%204.pdf> [consultat el 6 d'octubre de 2018]. 
aquesta qüestió cal fixar-lo a partir de l'article 45.3 CE, el qual estableix el següent:

Para quienes violen lo dispuesto en el apartado anterior, en los términos que la ley fije se establecerán sanciones penales o, en su caso, administrativas, así como la obligación de reparar el daño causado.

D'aquesta manera, la Constitució estableix un vincle entre la exigència de responsabilitats i la utilització irracional dels recursos naturals, en la que es podria enquadrar l'ús desproporcionat dels combustibles fòssils i la causació d'emissions massives de GEH, una vegada establerta l'evidència científica sobre la relació entre l'escalfament del sistema climàtic i l'augment de la presència de GEH a l'atmosfera per causa de l'activitat humana. D'altra banda, cal establir, així mateix, el vincle entre els apartats segon i tercer de l'article 45 CE i el seu apartat primer, on es reconeix el dret a un medi ambient adequat per al desenvolupament de la persona, associat al deure de conservar-lo, que cal lligar amb l'exigència de responsabilitats que deriva de l'apartat tercer, tal com he assenyalat. Crec que, en la mesura que el dret contingut a l'article 45.1 CE s'articuli com un dret procedimental per exigir el respecte del mandat constitucional de cura, és rellevant en relació amb la legitimació de cara a la litigació climàtica ${ }^{82}$.

Aquesta vinculació entre ambdós preceptes és una qüestió clau, al meu entendre, perquè permet construir l'eficàcia horitzontal del dret constitucional a un medi ambient adequat en relació amb l'exigència de responsabilitats per la transformació antròpica del clima, a la que he fet referència més amunt ${ }^{83}$. En

\footnotetext{
82 La faceta procedimental del dret a un medi ambient adequat es concreta en tres aspectes: la informació, la participación i l'accés a la justicia, tal com apunten José Antonio Razquin Lizarraga, i Ángel Ruiz de Apodaca Espinosa, Información, Participación y Justicia en Materia de Medio Ambiente. Comentario sistemático a la Ley 27/2006, de 18 de julio, Cizur Menor, Aranzadi, 2007, p.151. Aquesta perspectiva es deriva del que és el document de referència en aquesta matèria, a saber, el Conveni sobre l'accés a la informació, la participació del públic en la presa de decisions i l'accés a la justícia en matèria de medi ambient, fet a Aarhus el 25 de juny de 1998, ratificat per Espanya el 15 de desembre de 2004 (BOE núm. 40, de 14 de febrer de 2005).

${ }^{83}$ L'eficàcia horitzontal dels drets fonamentals parteix de la doctrina de la Drittwirkung der Grundrechte, que es va desenvolupar a Alemanya en els primers temps de vigència de la Llei fonamental, a partir de la Sentència Lüth (BVerfGE 7, 198 [Lüth]). En general, sobre aquesta qüestió, vid. Robert Alexy, Teoría de los derechos fundamentales, Centro de Estudios Constitucionales, Madrid, 1993 (edición castellana de Ernesto Garzón Valdés), p. 506ss.; Luis Prieto Sanchís, Estudios sobre derechos fundamentales, Debate. Madrid, 1990, p. 205ss.; i Ana Poyal Costa, "La eficacia de los derechos humanos frente a terceros", Revista de Derecho Político 34, 1991, p. 189-221; i Kaspar Wespi, Die Drittwirkung der Freiheitsrechte, Schulthess. Zurich, 1968.
} 
aquest sentit, la protecció dels drets constitucionals adquireix una dimensió objectiva (objektive Wertentscheidungen) que fonamenta la seva eficàcia entre els particulars ${ }^{84}$. En un context en què la situació de les persones ve, en bona part, definida per l'actuació dels actors corporatius, la qual cosa sembla evident en relació amb la causació el canvi climàtic, atenent a l'origen de les emissions de GEH, la projecció dels valors fonamentals de la Constitució, entre els que es troben els drets fonamentals, sobre els actors privats esdevé una qüestió crucial ${ }^{85}$.

Crec que l'eficàcia horitzontal dels drets fonamentals permet construir canals adequats per a l'exigència de responsabilitats en relació amb el canvi climàtic, a partir de la relació entre els apartats primer i tercer de l'article $45 \mathrm{CE}$. En relació amb això, cal remarcar que l'eficàcia horitzontal dels drets fonamentals entre els particulars ha estat generalment acceptada a Espanya, la qual cosa hauria d'obrir la possibilitat d'explorar-la en relació amb la litigació climàtica ${ }^{86}$. En definitiva, l'exigibilitat dels drets fonamentals davant dels actors privats enllaça amb el vincle entre deteriorament climàtic i lesions greus dels drets humans, la qual cosa constitueix el fonament per a l'exigència de responsabilitat i hauria de permetre ampliar les possibilitat de la litigació climàtica en el sistema constitucional espanyol ${ }^{87}$.

\section{CONCLUSIONS}

D'acord amb el que s'ha dit en les pàgines anteriors, cal concloure que el canvi climàtic suscita qüestions de relleu jurídic de manera indiscutible, en la mesura que es configura com a una amenaça per a la sostenibilitat i posa de manifest

\footnotetext{
${ }^{84}$ Vid. Robert Alexy, "Los derechos fundamentales..." cit., p. 34.

${ }^{85}$ Vid. Jörg Paul Müller, Elemente einer schweizerischen Grundrechtstheorie, Stämpfli. Berna, 1982, p. 80.

${ }^{86}$ Vid. Antonio Torres del Moral, "Naturaleza jurídica de los derechos constitucionales", en Balaguer Callejón, Derecho constitucional... cit., p. 509-510.

87 Vid. Antoni Pigrau, Jordi Jaria, "La aplicación de los principios rectores sobre empresas y derechos humanos en el caso de los daños al medio ambiente causados por empresas españolas en terceros países", Carmen Márquez Carrasco (ed.), España y la implementación de los principios rectores de las Naciones Unidas sobre empresas y derechos humanos: oportunidades y desafíos, Huygens. Barcelona, 2014, p. 305ss. Cal assenyalar aquí que Principis Rectors sobre les empreses i els drets humans (A/HRC/17/31, Assemblea General, 21 de març de 2011) estableixen que les empreses han de respectar els drets humans, la qual cosa, en particular implica que han d'abstenir-se de conculcar els drets de tercers i fer front a les conseqüències negatives en relació amb els drets humans en les que tinguin alguna participació.
} 
les inequitats del metabolisme social global, tot amenaçant la situació de milions de persones arreu del planeta, des del punt de vista del gaudi d'unes condicions de vida mínimament acceptables. En aquest sentit, els problemes de sostenibilitat i els dèficits pel que fa a la justícia es vinculen directament a la protecció dels drets humans, particularment, d'aquells que estan en una posició més vulnerable.

En un context de captura del regulador, les estratègies de control i exigència de responsabilitats a través de la litigació cobren importància, de manera que aquesta esdevé una via crucial per articular respostes efectives davant del canvi climàtic, tant des del punt de vista de la mitigació, com des del punt de vista de l'adaptació, alhora que un instrument imprescindible per protegir els drets humans amenaçats en un context de transformació del clima. Davant de la insuficiència de les respostes de caràcter regulador, de fet, la litigació esdevé una eina imprescindible per reaccionar i promoure les estratègies apropiades per garantir la sostenibilitat i maximitzar l'equitat en relació amb el canvi climàtic. Tot plegat és pot apreciar en l'enorme creixement que la litigació climàtica ha experimentat en el context global al llarg de la darrera dècada.

La translació de les possibilitats de la litigació climàtica a Espanya passen per una comprensió adequada del marc constitucional, que hauria de funcionar com a fonament per a les pretensions en aquest àmbit, tant en relació amb el control de les polítiques públiques com en relació amb l'assumpció de responsabilitats pel que fa a les conseqüències, particularment en relació amb els costos de l'adaptació. Pel que fa a això, cal reconèixer que el Tribunal Constitucional ha estat extremadament inactiu en relació amb la garantia d'un medi ambient adequat per al desenvolupament de la persona, la qual cosa s'ha fet evident en un aspecte sensible des del punt de vista de la litigació climàtica, com és el control de constitucionalitat de les polítiques energètiques.

Tanmateix, els problemes cal anar-los a trobar més aviat en l'actitud del Tribunal Constitucional, extraordinàriament deferent amb el legislador (estatal) i poc sensible a les qüestions ambientals, que no pas en el text de la Constitució. En aquest sentit, s'ha mostrat com l'article 45 CE pot operar com un paràmetre de control de constitucionalitat amb projecció sobre les polítiques públiques que contribueixen a l'emissió de $\mathrm{GEH}$, així com un fonament per explorar l'exigència 
de responsabilitats en relació amb les conseqüències negatives relacionades amb el canvi climàtic. Òbviament, més enllà de la construcció d'una argumentació jurídica a partir del marc constitucional present, cal notar les dificultats en relació amb la prova que es donen en aquest àmbit, però això no obsta per avançar en el disseny de pretensions fonamentades en relació amb la litigació climàtica a Espanya.

\section{BIBLIOGRAFIA}

Adelman, Sam, "Climate change, human rights and corporate accountability", Stephen Humphreys (ed.), Human Rights and Climate Change, Cambridge University Press. Cambridge, Nueva York, 2010, p. 159-179.

Albertí Rovira, Enoch, Autonomía política y unidad económica, Civitas. Madrid, 1995.

Alexy, Robert, Teoría de los derechos fundamentales, Centro de Estudios Constitucionales, Madrid, 1993 (edición castellana de Ernesto Garzón Valdés).

- "Los derechos fundamentales en el Estado constitucional democrático", Miguel Carbonell, (ed.), Neoconstitucionalismo(s), Trotta, Madrid, 2003, p. 3147.

Allen, Myles R., amb Richard Lord, “The blame game”, Nature 432, 2004, p. 551552.

Baber, Walter F., amb Robert V. Bartlett, a "The Role of International Law in Global Governance", John S. Dryzek, Richard B. Norgaard, David Schlosberg (eds.), The Oxford Handbook of Climate Change and Society, Oxford University Press. Oxford, 2011, p. 653-665.

Boyle, Alan, "Human Rights and the Environment: Where Next?", European Journal of International Law 23(3), 2012, p. 613-642.

Brunnée, Jutta, "Climate Change, global environmental justice and international environmental law", Jonas Ebbeson, Phoebe Okowa (eds.), Environmental Law and Justice in Context, Cambridge University Press. Cambridge, Nueva York, 2009, p. 316-332. 
Clarkson, Stephen, amb Stepan Wood, A Perilous Imbalance. The Globalization of Canadian Law and Governance, UBC Press. Vancouver, Toronto, 2009.

Corry, Olaf, "What is a (global) polity?", Review of International Studies 36(1), 2010, p. 157-180.

Crutzen, Paul J.; amb Eugene F. Stoermer, "The «Anthropocene»", Global Change Newsletter 41, 2000, p. 17-18.

Dal Bó, Ernesto, "Regulatory Capture: A Review", Oxford Review of Economic Policy 22(2), 2006, p. 203-225.

Dolzer, Rudolf, "Die internationale Konvention zum Schutz des Klimas und das allgemeine Völkerrecht", Ulrich Beyerlin, Michael Bohte, Rainer Hofmann, ErnstUlrich Petersmann (eds.), Recht zwischen Umbruch und Bewahrung. Festschrift für Rudolf Bernhardt, Springer. Berlin, Heidelberg, Nova York, 1995, p. 957-973. Dryzek, John S., amb Richard B. Norgaard, David Schlosberg, "Climate Change and Society: Approaches and Responses", John S. Dryzek, Richard B. Norgaard, David Schlosberg (eds.), The Oxford Handbook of Climate Change and Society, Oxford University Press. Oxford, 2011, p. 3-17.

Dunlap, Riley E., amb Aaron M. McCright, "Organized Climate Change Denial", John S. Dryzek, Richard B. Norgaard, David Schlosberg (eds.), The Oxford Handbook of Climate Change and Society, Oxford University Press. Oxford, 2011, p. 144-160.

Elizalde Carranza, Miguel Ángel, "Desarrollo y cambio climático", Revista Catalana de Dret Ambiental 1(1), 2010.

Evans, Peter, "¿El eclipse del Estado? Reflexiones sobre la estatalidad en la época de la globalización", Miguel Carbonell, Rodolfo Vázquez (eds.), Globalización y Derecho, Ministerio de Justicia y Derechos Humanos. Quito, 2009, p. 39-71.

Falk, Richard, "The second cicle of ecological urgency: an environmental justice perspective", Jonas Ebbeson, Phoebe Okowa (eds.), Environmental Law and Justice in Context, Cambridge University Press. Cambridge, Nova York, 2009, p. 39-54. 
Fischer-Kowalski, Marina, "Society's Metabolism: The Intellectual History of Materials Flow Analysis, Part I, 1860-1970", Journal of Industrial Ecology 2, 1998, p. 61-78.

- amb Walter Hüttler, "Society's Metabolism: The Intellectual History of Materials Flow Analysis, Part II, 1980-1998”, Journal of Industrial Ecology 2, 1998, p. 107-136.

García de Enterría, Eduardo, La Constitución como norma y el Tribunal Constitucional, Civitas, Madrid, 1985 (3a. edició).

Gardiner, Stephen M., "Climate Justice”, John S. Dryzek, Richard B. Norgaard, David Schlosberg (eds.), The Oxford Handbook of Climate Change and Society, Oxford University Press. Oxford, 2011, p. 309-322.

González García, Julio, "STC 152/2017, sobre el caso Castor: un problema jurídica, social y políticamente inacabado", Blog de la Revista Catalana de Dret Públic, 1 de febrer de 2018, disponible a <http://eapcrcdp.blog.gencat.cat/2018/02/01/stc-152-2017-sobre-el-caso-castor-unproblema-juridica-social-y-politicamente-inacabado-julio-gonzalez-garcia/>.

Guerry, Anaïs, "A reflection on some legal aspects of decision control in the energy transition process: a comparison of France and Germany", Jordi Jaria i Manzano, Nathalie Chalifour, Louis J. Kotzé (eds.), Energy, Governance and Sustainability, Edward Elgar. Cheltenham, Northampton, 2016, p. 194ss.

Humphreys, Stephen, "Competing claims: human rights and climate harms", Stephen Humphreys (ed.), Human Rights and Climate Change, Cambridge University Press. Cambridge, Nueva York, 2010, p. 37-68.

Intergovernmental Panel on Climate Change, Climate Change 2014. Synthesis Report, 2014.

Jaria i Manzano, Jordi, "Environmental Justice, Social Change and Pluralism", IUCN Academy of Environmental Law e-Journal 1, 2012, p. 18-29.

- "Jurisprudencia constitucional en materia de protección del medio ambiente (Segundo semestre 2014)", Revista Catalana de Dret Ambiental 5(2), 2014. 
- "Derechos y medio ambiente", Albert Noguera Fernández, Adoración Guamán Hernández, Lecciones sobre Estado social y derechos sociales, Tirant lo Blanch. Valencia, 2014, p. 577-615.

- "Constitución, desarrollo y medio ambiente en un contexto de crisis", Revista Catalana de Dret Ambiental 8(1), 2017.

- "Jurisprudencia constitucional en materia de protección del medio ambiente (primer semestre 2018)", Revista Catalana de Dret Ambiental 9(1), 2018.

- $\quad$ "Consideracions constitucionales en relación con la protección de las víctimes de violacions de los derechos humanos causades por la actividad de las empresas españolas en el extranjero", Maria Chiara Marullo, Francisco Javier Zamora Cabot (eds.), Empresas y derechos humanos. Temas actuales, Editoriale Scientifica. Nàpols, 2018, p. 69-89.

Jasanoff, Sheila, "Cosmopolitan Knowledge: Climate Science and Global Civic Epistemology", John S. Dryzek, Richard B. Norgaard, David Schlosberg (eds.), The Oxford Handbook of Climate Change and Society, Oxford University Press. Oxford, 2011, p. 129-143.

Kiss, Alexandre, amb Dinah Shelton, Manual of European Environmental Law, Cambridge University Press. Cambridge, 1993.

Kjellén, Bo, "Justice in global environmental negotiations: the case of desertification", Jonas Ebbeson, Phoebe Okowa (eds.), Environmental Law and Justice in Context, Cambridge University Press. Cambridge, Nova York, 2009, p. 333-347-

Kotzé, Louis J., "Arguing Global Environmental Constitutionalism", Transnational Environmental Law 1, 2012, p. 199-233.

- Global Environmental Constitutionalism in the Anthropocene, Hart. Oxford, Portland, 2016.

Lazarus, Richard J., "Pursuing «Environmental Justice»: The Distributional Effects of Environmental Protection", Land Use and Environment Law Review, 1994, p. 263-333. 
Lowe, Thomas; amb Katrina Brown, Suraje Dessai, Miguel de França Doria, Kat Haynes, Katharine Vincent, "Does tomorrow ever come? Disaster narrative and public perceptions of climate change", Public Understanding of Science 15(4), 2006, p. 435-457.

Manaster, Kenneth A., "Law and the Dignity of Nature: Foundations of Environmental Law", Land Use and Environment Law Review, 1978, p. 3-26.

Malm, Andreas, amb Alf Hornborg, "The geology of mankind? A critique of the Anthropocene narrative", The Anthropocene Review 1 (1), 2014, p. 62-69.

- Fossil Capital. The Rise of Steam Power and the Roots of Global Warming, Verso. Londres, 2016.

Martín Mateo, Ramón, Tratado de Derecho Ambiental (I), Trivium. Madrid, 1991. Martínez-Vela, Carlos A., "World Systems Theory", Research Seminar in Engineering Systems, MIT, Cambridge (Mas.), 2001, $<$ http://web.mit.edu/esd.83/www/notebook/WorldSystem.pdf>.

Mary Robinson Foundation, "Principles of Climate Justice", disponible a $<$ https://www.mrfcj.org/principles-of-climate-justice/>.

Mesa Cuadros, Gregorio, "Elementos para una teoría de la justicia ambiental", Gregorio Mesa Cuadros (ed.), Elementos para una teoría de la Justicia Ambiental y el Estado Ambiental de Derecho, Universidad Nacional de Colombia. Bogotá, 2011, p. 25-62.

Mickelson, Karin, "Competing narratives of justice in North-South environmental relations: the case of ozone layer depletion", Jonas Ebbeson, Phoebe Okowa (eds.), Environmental Law and Justice in Context, Cambridge University Press. Cambridge, Nueva York, 2009, p. 297-315.

Müller, Jörg Paul, Elemente einer schweizerischen Grundrechtstheorie, Stämpfli. Berna, 1982.

Müller-Bromley, Nicolai, Staatszielbestimmung Umweltschutz im Grundgesetz? Rechtsfragen der Staatszielbestimmung als Regelungsform der Staatsaufgabe Umweltschutz, Eric Schmidt. Berlín, 1990. 
Nogueira López, Alba, "Crisis económica y cambios estructurales en el régimen de ejercicio de actividades", Avelino Blasco Esteve (coord.), El Derecho público de la crisis económica. Transparencia y sector público. Hacia un nuevo Derecho administrativo, INAP. Madrid, 2011, p. 121-187.

- con Susana Borràs Pentinat, Rosa Giles Carnero, Jordi Jaria Manzano, "Marco general. El medio ambiente en los tiempos de globalización neoliberal", Francisco Javier Sanz Larruga, J. José Pernas García (dirs.), Jennifer Sánchez (coord.), Derecho ambiental para una economía verde. Informe ECOVER, Thomson Reuters-Aranzadi. Cizur Menor, 2016, p. 21-48.

Penrose, Roger, La nueva mente del emperador, Grijalbo-Mondadori. Barcelona, 1991 (edición castellana de Javier García Sanz).

Peters, Anne, "Global Constitutionalism", Michael Gibbons (ed.), The Encyclopedia of Political Thought, Wiley-Blackwell. Bognor Regis, 2015, p. 1-4.

Petitpierre-Sauvaine, Anne, "La responsabilité du polleur: révision de la LPE et droit souhaitable", La semaine judiciaire 2, 1996, p. 17-33.

Porras Ramírez, José María, "Caracterización y garantía de los derechos de prestación en el Estado constitucional”, Francisco Balaguer Callejón (coord.), Derecho constitucional y cultura. Estudios en homenaje a Peter Häberle, Tecnos. Madrid, 2004, p. 659-673.

Poyal Costa, Ana, "La eficacia de los derechos humanos frente a terceros", Revista de Derecho Político 34, 1991, p. 189-221.

Pigrau, Antoni, amb Jordi Jaria, "La aplicación de los principios rectores sobre empresas y derechos humanos en el caso de los daños al medio ambiente causados por empresas españolas en terceros países", Carmen Márquez Carrasco (ed.), España y la implementación de los principios rectores de las Naciones Unidas sobre empresas y derechos humanos: oportunidades y desafíos, Huygens. Barcelona, 2014, p. 301-332.

Prieto Sanchís, Luis, Estudios sobre derechos fundamentales, Debate. Madrid, 1990.

Ribot, Jesse, "Cause and Response: Climate Vulnerability in the Anthropocene", Journal of Peasant Studies 41(5), 2014, p. 667-705. 
Roberts, J. Timmons; con Bradley C. Parks, "Ecologically Unequal Exchange, Ecological Debt, and Climate Justice. The History and Implications of Three Related Ideas for a New Social Movement", International Journal of Comparative Sociology 50(3-4), 2009, p. 385-409.

Rocha, Marcia, amb Mario Krapp, Johannes Guetschow, Louise Jeffery, Bill Hare, Michiel Schaeffer, Historical Responsibility for Climate Change - from countries emissions to contribution to temperature increase, Climate Analytics, novembre 2015, disponible a <http://climateanalytics.org/files/historical_responsibility_report_nov_2015.pdf>. Ruiz Robledo, Agustín, "Un componente especial de la Constitución económica: La protección del medio ambiente", Revista Andaluza de Administración Pública 14, 1993, p. 27-53.

Stec, Stephen, "Environmental justice through courts in countries in economic transition", Jonas Ebbeson, Phoebe Okowa (eds.), Environmental Law and Justice in Context, Cambridge University Press. Cambridge, Nueva York, 2009, p. $158-175$.

Steffen, Will, "A Truly Complex and Diabolical Policy Problem", John S. Dryzek, Richard B. Norgaard, David Schlosberg (eds.), The Oxford Handbook of Climate Change and Society, Oxford University Press. Oxford, 2011, p. 21-37.

Stiglitz, Joseph, The Price of Inequality, Norton. Nueva York, Londres, 2013.

Taylor, Peter J., amb Colin Flint, Geografía política. Economía-mundo, estadonación y localidad, Trama. Madrid, 2002 (2ª . edición castellana a cargo de Adela Despujol Ruiz-Jiménez y Heriberto Cairo Carou).

Toledo, Víctor M., "El metabolismo social: una nueva teoría socieconómica", Relaciones 136, 2013, p. 41-71.

Torres del Moral, Antonio, "Naturaleza jurídica de los derechos constitucionales", Francisco Balaguer Callejón (coord.), Derecho constitucional y cultura. Estudios en homenaje a Peter Häberle, Tecnos. Madrid, 2004, p. 497-516.

United Nations Environment Programme, The Status of Climate Change Litigation - A Global Review, 2017. 
Wallerstein, Immanuel, El moderno sistema mundial. I. La agricultura capitalista y los orígenes de la economía-mundo en el siglo XVI, Siglo XXI. Madrid, 2010 $\left(2^{\mathrm{a}}\right.$. edición castellana a cargo de Antonio Resines).

Wespi, Kaspar, Die Drittwirkung der Freiheitsrechte, Schulthess. Zurich, 1968. 